\title{
New data on distribution, morphology and ecology of Oedogonium capillare Kützing ex Hirn (Oedogoniales, Chlorophyta) in Poland
}

\author{
Pikosz Marta* \& Messyasz Beata
}

Department of Hydrobiology, Faculty of Biology, Adam Mickiewicz University, Umultowska 89, 61-614 Poznań, Poland

* corresponding author (e-mail: pikosz@amu.edu.pl)

\begin{abstract}
Algological investigations were focused on taxonomy, chorology and ecology of threatened filamentous green alga species in Poland. Studies on Oedogonium capillare Kützing ex Hirn growing in large quantities in association with Cladophora rivularis (Linnaeus) Hoek in pond were conducted. The aim of these studies was to describe the distribution, ecology and morphology of $O$. capillare as part of a more comprehensive study of this filamentous green alga. It is the eighth record in Poland for $O$. capillare. Filaments of $O$. capillare were grown over a wide $\mathrm{pH}$ range (7.3-9.6) and in high variability of nutrients. Vegetative cells, oogonia and antheridia were observed, which allowed taxonomic identification. $O$. capillare occurs in eutrophic waters which requires protection of its habitat.
\end{abstract}

Key words: Oedogonium capillare, Poland, pond, filamentous green algae

\section{Introduction}

Macroscopic filamentous algae, including Chlorophyta, may form patches (mats) on the water surface (free-floating thalli) and in the benthos (thalli attached to the bottom or macrophytes) in lakes and rivers. These algae play an important role in functioning of aquatic ecosystems. Oedogonium species belong to Chlorophyta, include 534 species (Mahato 1999) and are classified as filamentous green algae. These species are cosmopolitan in freshwater ecosystems and prefer stagnant waters, such as small ponds, pools, roadside ditches, marshes, oxbows, lakes, reservoirs, rivers (Mrozińska-Weeb 1976; Burchardt 1977; Sieminiak 1979; Kuczyńska-Kippen 2009; Pikosz \& Messyasz 2015). However, most Oedogonium taxa were found in small water bodies (Szymańska et al. 2015). Oedogonium species may grow throughout the year, but maximum reproductive development in the lowlands was observed in June and less in August (Mrozińska-Webb 1976). Young thalli are attached to macrophytes (mainly on the Glyceria maxima (Hartm.) Holmh., Equisetum fluviatile L. and Phragmites australis (Cov.) Trin. ex
Steud.) by a basal holdfast and, as mature organisms, may form mats on the surface of water. Oedogonium mostly form multispecies mats and might be associated with Spirogyra, Rhizoclonium, Cladophora (Khanum 1982; Messyasz et al. 2015).

The first records of Oedogonium species in freshwater habitats from Poland were reported in the late $19^{\text {th }}$ century by Hilse (1860), Gołowin (1964), Kirchner (1878), Kozłowski (1895) and Gutwiński (1897). Mrozińska was the first Polish phycologist examining this group in details (in terms of morphology, phenology, ecology and distribution) and described more than 400 species (including varieties and forms), mainly from southern Poland (Mrozińska 1958, 1981, 1984). According to Mrozińska (1991), there are 20 groups of Oedogonium based on phylogenetic analysis. Szymańska et al. (2015) presented species of Oedogoniales from north-eastern Poland and described two species of Oedogonium, namely Oedogonium fremyi and Oedogonium irregular, new for the algal flora of Poland. The first and detailed information of rare Oedogonium capillare was produced by Mrozińska (1984) and Sieminiak (1979), who described two forms of this 
species: $O$. capillare f. stagnale Hirn and $O$. capillare f. capillare Kützing ex Hirn.

The main aim of the study was to review distribution and morphology of the $O$. capillare, mainly in Poland and to provide new information about this taxon. In our research, $O$. capillare is characterized by a slightly oval oogonium (not visible typical, cylindrical shape) and grows in ponds. O. capillare was found only in a few places in Poland, so the information on its distribution and ecological requirements is important. Because of its rarity, this species is considered as threatened in Poland and is placed in the Red List of Algae in the category: vulnerable (VU) (Siemińska et al. 2006).

\section{Material and methods}

Studies on $O$. capillare were carried out during summer (July-August) in 2014 in a small (area 29.48 a; length $81.86 \mathrm{~m}$; width $47.29 \mathrm{~m}$ ), shallow (depth $1 \mathrm{~m}$ ), agricultural pond in Konojad in Wielkopolska Voivodeship, Poland (N52 ${ }^{\circ} 10^{\prime} 14.17$ ", E16 $31 ' 24.51$ '). During the study period, water depth ranged from 50 up to $70 \mathrm{~cm}$. Based on literature data and our own research, sites of the $O$. capillare occurrence in Poland were marked on the map (Fig. 1).
Terminology of recorded macrophytes follows Mirek et al. (2002).

Filaments appeared concentrated, tightly covering a significant surface of water, which reached up to $70 \%$ of the pond. The filaments of free-floating green algae (like mats) were taken from the surface by hand, placed in a plastic container and transported to the laboratory. Next, the filaments were rinsed repeatedly with distilled water in order to remove any biotic and abiotic particles attached to them. The specimens were examined with the LM and the ProCap program. The length, width and shape of cells, and number of pyrenoids were measured. Distinctive features were compared with morphometric data for O. capillare recorded in Poland and Europe, included in the Mrozińska key (1984), Sieminiak (1979), Tiffany (1937), Novis (2003) and Venkataraman \& Natarajan (1959).

Physico-chemical parameters of water: temperature $\left({ }^{\circ} \mathrm{C}\right)$, electrolytic conductivity $\left(\mu \mathrm{S} \cdot \mathrm{cm}^{-1}\right)$, oxygen saturation $\left(\mathrm{mg} \cdot \mathrm{L}^{-1}\right)$, TDS $\left(\mathrm{mg} \cdot \mathrm{L}^{-1}\right)$ and $\mathrm{pH}$ at the examined sites were measured by YSI Professional Plus handheld multiparameter gauge. Water samples were also taken for detailed laboratory analyses to measure the content of nitrogen, phosphorus and sulphates with HACH DR 2800 spectrophotometer (Hach Lange 2006).

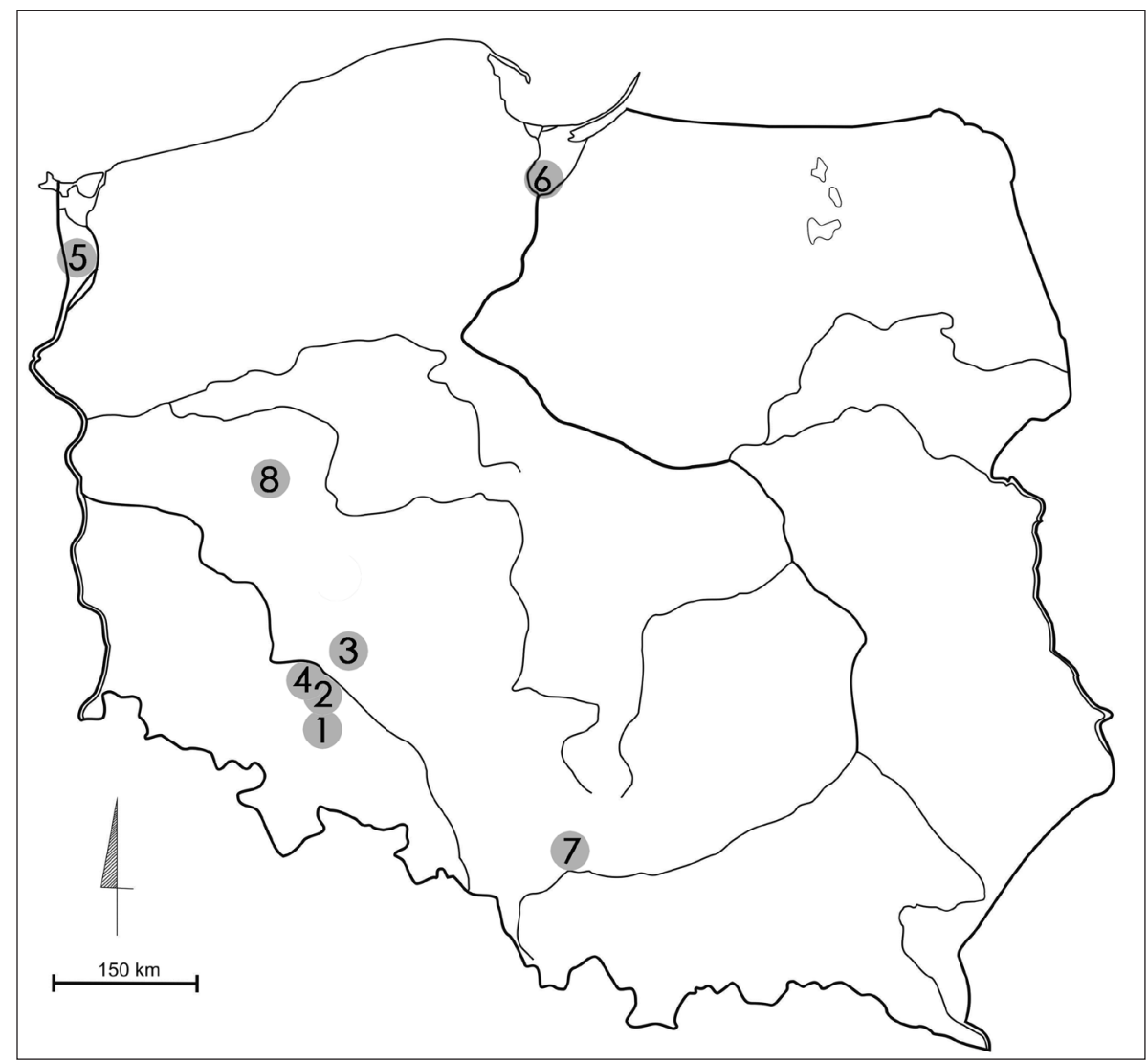

Fig. 1. The location of Oedogonium capillare in Poland

Explanations: 1 - Strzelin, 2 - Ołtaszyn, 3 - Domaszczyn, 4 - Sołtysowice, 5 - Szczecin, 6 - Koniecwałd, 7 - Przeczyce, 8 - Konojad 
Table 1. Physical and chemical parameters of water for Oedogonium capillare in midfield pond in $2014(\mathrm{n}=5)$

\begin{tabular}{lccccr}
\hline \multicolumn{1}{c}{ Parameter } & Unit & Minimum & Maximum & Mean & \multicolumn{1}{c}{$\mathrm{SD}$} \\
\hline Temperature & ${ }^{\circ} \mathrm{C}$ & 20.1 & 22.3 & 21.5 & 0.86 \\
$\mathrm{EC}$ & $\mu \mathrm{S} \cdot \mathrm{cm}^{-1}$ & 875 & 963 & 925 & 37.70 \\
$\mathrm{pH}$ & - & 7.3 & 9.6 & 8.3 & 1.00 \\
$\mathrm{OS}$ & $\mathrm{mg} \cdot \mathrm{L}^{-1}$ & 9.6 & 22.5 & 16.3 & 6.10 \\
$\mathrm{TDS}$ & $\mathrm{mg} \cdot \mathrm{L}^{-1}$ & 532 & 642 & 600 & 43.50 \\
$\mathrm{NO}_{3}^{-}$ & $\mathrm{mg} \cdot \mathrm{L}^{-1}$ & 0.1 & 0.4 & 0.26 & 0.11 \\
$\mathrm{NH}_{3}$ & $\mathrm{mg} \cdot \mathrm{L}^{-1}$ & 0.05 & 0.2 & 0.14 & 0.06 \\
$\mathrm{NH}_{4}$ & $\mathrm{mg} \cdot \mathrm{L}^{-1}$ & 0.06 & 0.23 & 0.17 & 0.07 \\
$\mathrm{PO}_{4}$ & $\mathrm{mg} \cdot \mathrm{L}^{-1}$ & 0.07 & 0.25 & 0.11 & 0.08 \\
$\mathrm{SO}_{4}$ & $\mathrm{mg} \cdot \mathrm{L}^{-1}$ & 90 & 115 & 101 & 11.26 \\
$\mathrm{Cl}^{-}$ & $\mathrm{mg} \cdot \mathrm{L}^{-1}$ & 86 & 122 & 101 & 16.03 \\
\hline
\end{tabular}

Explanations: SD - Standard Deviation, EC - Electrolytic Conductivity, OS - Oxygen Saturation, TDS - Total Dissolved Substance

\section{Results}

The polyalgal mats in the pond in Konojad were formed by representatives of green algae: $O$. capillare Kützing ex Hirn and Cladophora rivularis (Linnaeus) Hoek. It was the eighth described site of occurrence of O. capillare in Poland (Fig. 1). Oedogonium filaments appeared at the end of June, and in July-August were found dominant in a macroalgal mat. $O$. capillare grew over a broad $\mathrm{pH}$ range (7.3-9.6) and presented wide tolerance to the content of nutrients in water (Table 1). Significant changes were observed in the content of nitrates, ammonia nitrogen, phosphates and rather stable values of sulphates and chlorides were also recorded. Other values of physicochemical habitat parameters (electrolytic conductivity, total dissolved substance, water temperature, oxygen saturation) also achieved large values and amounted to $875-963 \mu \mathrm{S} \cdot \mathrm{cm}^{-1}, 600 \mathrm{mg} \cdot \mathrm{L}^{-1}$, 20-22 ${ }^{\circ} \mathrm{C}, 9.6-22.5 \mathrm{mg} \cdot \mathrm{L}^{-1}$ respectively (Table 1 ).
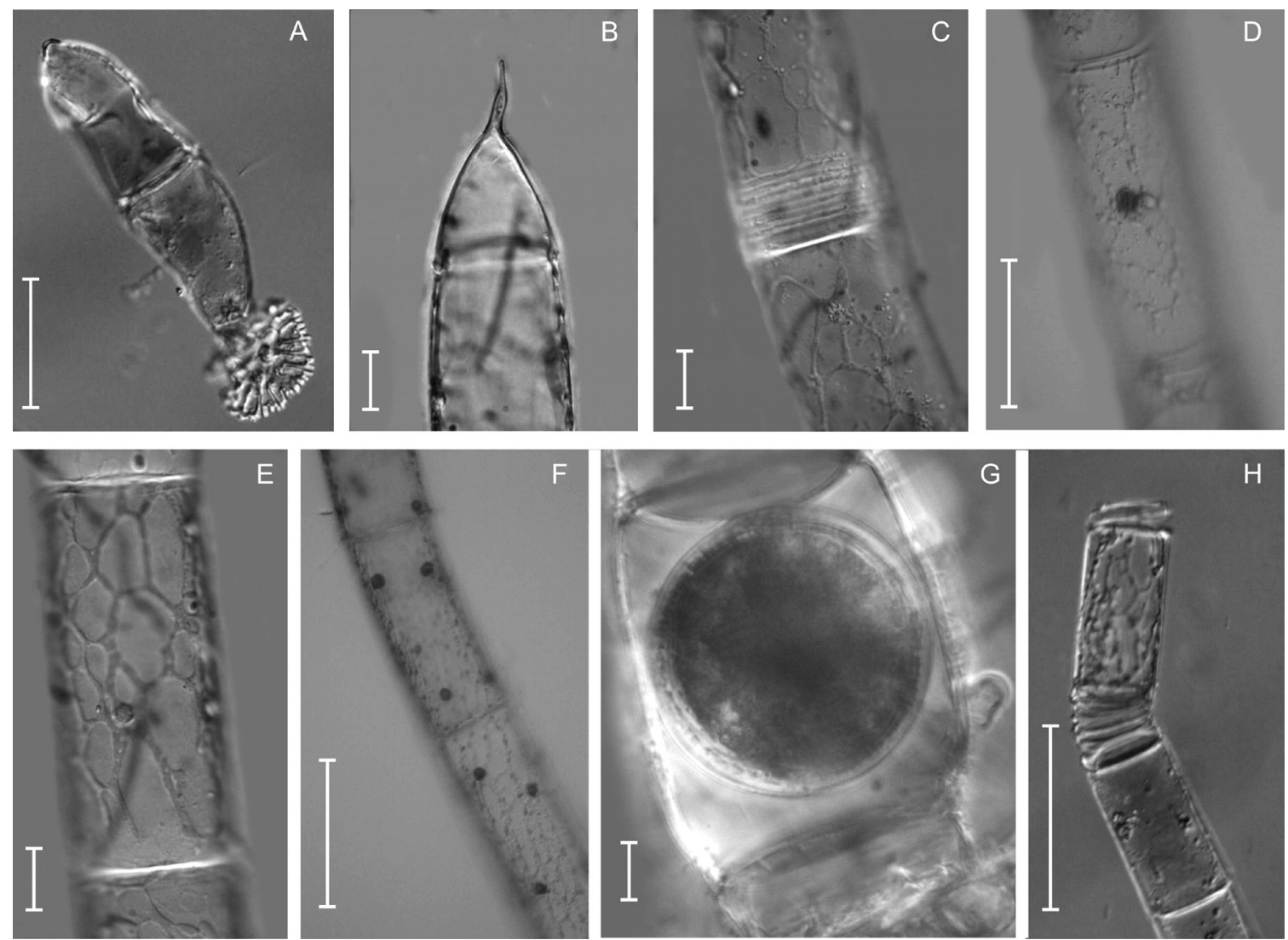

Fig. 2. Oedogonium capillare from the pond in Konojad (photograph by M. Pikosz, 2014)

Explanations: A - young thalli, B - apical cell, C - apical cap, D - nucleus, E - vegetative cell with reticulate chloroplast, F - pyrenoids in the cell, G oogonium - generative cell, $\mathrm{H}$ - antheridial cells; scale, A, D, F - 50 $\mu \mathrm{m}, \mathrm{B}, \mathrm{E}-15 \mu \mathrm{m}, \mathrm{C}, \mathrm{G}-10 \mu \mathrm{m} ; \mathrm{H}-100 \mu \mathrm{m}$ 
Table 2. Comparison of morphometric features (minimum-maximum) of Oedogonium capillare from different site in USA, New Zeland, India and Poland

\begin{tabular}{lcccccc}
\hline \multicolumn{1}{c}{ Features } & Unit & $\begin{array}{c}\text { Lake Erie } \\
\text { USA }^{1}\end{array}$ & $\begin{array}{c}\text { Chatham Island } \\
\text { New Zeland }\end{array}$ & $\begin{array}{c}\text { Kerala } \\
\text { India }^{3}\end{array}$ & $\begin{array}{c}\text { Przemsza } \\
\text { Poland }^{4}\end{array}$ & $\begin{array}{c}\text { Konojad } \\
\text { Poland }^{5}\end{array}$ \\
\hline width of veg. cells & {$[\mu \mathrm{m}]$} & $35-56$ & $33-40$ & $34-46$ & $35-60$ & $37-56$ \\
length of veg. cells & {$[\mu \mathrm{m}]$} & $36-120$ & $31-55$ & $46-76$ & $35-120$ & $30-102$ \\
width of oogonium & {$[\mu \mathrm{m}]$} & $40-60$ & $45-55$ & $42-46$ & $35-65$ & $30-52$ \\
length of oogonium & {$[\mu \mathrm{m}]$} & $35-75$ & $39-54$ & $34-57$ & $45-75$ & $30-55$ \\
width of oospory & {$[\mu \mathrm{m}]$} & $30-50$ & $43-49$ & 36 & $30-52$ & n.d. \\
length of oospory & {$[\mu \mathrm{m}]$} & $35-65$ & $32-48$ & $30-38$ & $35-65$ & n.d. \\
width of internal antheridium & {$[\mu \mathrm{m}]$} & $30-48$ & $22-26$ & $34-38$ & $30-48$ & $28-38$ \\
width of external antheridium & {$[\mu \mathrm{m}]$} & $5-10$ & $4-6$ & $7-11$ & $5-10$ & n.d. \\
number of pyrenoids & No. & n.d. & $5-12$ & n.d. & n.d. & $6-10$ \\
diameter of pyrenoids & {$[\mu \mathrm{m}]$} & n.d. & n.d. & n.d. & n.d. & $3-5$ \\
shape of pyrenoids & - & n.d. & n.d. & n.d. & n.d. & discoid \\
\hline
\end{tabular}

Explanations: veg. cells - vegetative cells, n.d. - no data; ${ }^{1}$ - Tiffany $(1937),{ }^{2}$ - Novis (2003), ${ }^{3}$ - Venkataraman \& Natarajan $(1959),{ }^{4}-$ Sieminiak $(1979)$ ${ }^{5}$ - own research

O. capillare filaments and their cells were subjected to morphometric analysis. Filaments of $O$. capillare were multicellular, unbranched and composed of basal, tapered apical and vegetative cells (Fig. 2A-B). Vegetative cells had characteristic cap cells with rings (Fig. 2C), one nucleus (Fig. 2D) and reticulate multipyrenoid chloroplasts (Fig. 2E-F). Cylindrical cells of O. capillare were 37-56 $\mu \mathrm{m}$ wide and 30-102 $\mu \mathrm{m}$ long with 6 , 8 or 10 discoid pyrenoids, $3-5 \mu \mathrm{m}$ in diameter and one nucleus in the central part of the cell $(6-10 \mu \mathrm{m})$. Young organisms were attached to substrata such as macrophytes or stones by a holdfast - a specially adapted cell. In the later stage of development, free floating filaments were observed. Only single individuals of this species formed generative cells during research and, on this basis, it was possible to classify them to species as $O$. capillare. August was a reproductive season for solitary, spherical oogonia with $\sim 30 \mu \mathrm{m}$ in diameter to be attached to female filaments (Fig. 2G). Antheridia 28-38 $\mu \mathrm{m}$ wide, intercalary, 4-6 in series were noted in male filaments (Fig. 2H).

\section{Discussion}

The genus Oedogonium (Oedogoniaceae, Chlorophyta) consists of species, which are present only in freshwater ecosystems. Oedogonium grows in different types of ecosystems from reservoirs, lakes, ponds to rivers and drainage ditches. More than 100 species occur in Poland (Central Europe), of which $O$. intermedium Wittrock and $O$. undulatum (Brébisson) Al. Braun are the most widespread (Mrozińska 1984). O. capillare is a cosmopolitan species in freshwater habitats. It was found in Europe, North America, Africa, Asia and New Zealand (Venkalaraman \& Natarajan 1959; Day et al.
1995; Baba et al. 2011; Broady et al. 2012). Untill 2015, O. capillare was found in freshwaters of Europe taking into consideration sites in Britain (Whitton et al. 1998; Huxley \& Pentecost 2002), 6 records in Romania (Caraus 2012), 16 locations (14 for O. capillare and 2 for O. capillare f. stagnale) in Spain (Alvárez \& Gallardo 1986; Cambra et al. 1998), 4 in Sweden, 1 (for O. capillare var. fluitans) in Germany and in such other countries as Denmark, Finland, France, Germany, Italy, Spain, Sweden (Venkalaraman \& Natarajan 1959). In Poland, this taxon was recorded in 1860 (Hilse 1860) in a pool and a ditch in Strzelin (near Wrocław) where it appeared from June till October and in Domaszczyn (Hilse 1860) (Fig. 2). Mrozińska-Webb (unpublished) observed this taxon in a reservoir in Koniecwałd (Malbork) and in Upper Silesia in the Przemsza River in February 1978 in alkaline $(8 \mathrm{pH})$ water at $6^{\circ} \mathrm{C}$ (Sieminiak 1979). A location of the $O$. capillare in Wielkopolska Voivodeship was recorded for the first time in 2012, in Konojad village (Pikosz 2012) where it also appeared in the following years forming mats, which occupied large area.

The occurrence of Oedogonium species in any particular location seems to be governed mainly by biotic and abiotic factors. Abundance of Oedogonium species depends on temperature, light intensity and type of habitats. Sieminiak (1979) observed a community of $O$. capillare at $6^{\circ} \mathrm{C}$ on a muddy river bottom . Sampling sites characterized by near neutral $\mathrm{pH}$ values were similar to measurements from lake Erie (Tiffany 1937), stream in New Zealand (Novis 2003) and from the Przemsza River (Sieminiak 1979), where O. capillare were also noted. However, it should be noted that Oedogonium rarely reproduces in flowing waters (Mrozińska 1984). Ponds, where water heats 
up quickly, is a type of ecosystem, which is mostly inhabited by Oedogonium species (Mrozińska 1984). In the Konojad pond, abiotic parameters allowed large development of filaments, which later formed considerable floating mats on the pond surface. The obtained results showed that $O$. capillare occurred in water at $20^{\circ} \mathrm{C}$ and high nutrient and sulphate concentrations played an important factor in algae growth. In previous studies, sulphate content was not measured in waters where $O$. capillare developed. However, our studies indicate that filaments of this species were growing in the presence of high concentrations of this compound. O. capillare occurred with C. rivularis corroborating the assumption of Khanum (1982), that Oedogonium generally never formed independent mats, but coexisted with other species, such as Spirogyra and Rhizoclonium.
The specimens were slightly similar to those described previously (Table 2). Maximum vegetative cell lengths (more than $100 \mu \mathrm{m}$ ) were most similar to those of O. capillare from Lake Erie (Tiffany 1937) and from Poland (Mrozińska 1984). Oogonia, in these specimens, were spherical and more rounded than in the illustrations of Novis (2003) and Mrozińska (1984). In most specimens in our research, we observed mainly oval oogonia.

Acknowledgments. The study was supported, in part, by the National Centre for Science, grant No. 2014/13/B/NZ8/04690 and by a grant from the National Centre for Research and Development in Poland (No. PBS/1/A1/2/2012 - Innovative technology of seaweed extracts - omponents of fertilizers, feed and cosmetics). Marta Pikosz is a scholarship holder of Adam Mickiewicz University Foundation for the academic year 2015/2016.

\section{References}

Alvárez C. M. \& Gallardo T. 1986. Catálogo de las algas continentales españolas. IV. Chlorophyceae Wille in Warming 1884. Prasinophyceae T. Christensen ex Silva 1980. Acta Bot. Malacitana, 11: 17-38.

Baba A. I., Sofi A. H., Bhat S. U. \& Pandit A. K. 2011. Periphytic Algae of River Sindh in the Sonamarg Area of Kashmir Valley. Journal of Phytology 3(6): 01-12.

Broady P. A., Flint E. A., Nelson W. A., Cassie C. V., De Winton M. D. \& Novis P. M. 2012. Phylum Chlorophyta and Charophyta: green algae. In: D. P. GORDON (eds.). New Zealand inventory of biodiversity. Volume Three. Kingdoms Bacteria, Protozoa, Chromista, Plantae, Fungi, pp. 347-381. Christchurch, Canterbury University Press

BurCHARDT L. 1977. Zmiany w składzie fitoplanktonu jeziora Pątnowskiego odbiornika wód podgrzanych i ścieków z cukrowni (1972/73). Uniwersytet im. Adama Mickiewicza w Poznaniu, Seria Biologia 8: 1-117.

Cambra S. J., Álvarez C. M. \& Aboal S. M. 1998. Lista florística y bibliográfica de los clorófitos (Chlorophyta) de la Península Ibérica, Islas Baleares e Islas Canarias, Burgos: Asociación Española de Limnología 1-614.

CARAus I. 2012. Algae of Romania. A distributional checklist of actual algae. Version 2.3 third revision. Bacau, Univ. Bacau.

Day S. A., Wickham R. P., Entwisl T. J. \& Tyler P. A. 1995. Bibliographic check-list of non-marine algae in Australia. Flora of Australia Supplementary Series 4(1-7): 1-276.

GoŁowin S. 1964. Glony torfowisk Chlebowo (pow. Oborniki, woj. poznańskie). Fragm. Florist. Geobot. 10(1): 121-169.
GUTwIŃSKI R. 1897. Wykaz glonów zebranych z okolic Wadowic-Makowa. Spraw. Komis. Fizjogr. AU 32: 97-217.

Hach Lange 2006. DR 2800 Spektrofotometr. Metodyki.

HiLse W. 1860. Beitraege zur Algen - und Diatomeen-Kunde Schlesiens, insbesondere Strehlens. Jahresber. Schles. Ges vaterl. Cult. 38: 75-86.

Huxley R. \& Pentecost A. 2002. Order Oedogoniales. In: D. M. John, B. A. Whitton \& A. J. Brook (eds.). The Freshwater Algal Flora of the British Isles. An identification guide to freshwater and terrestrial algae, pp. 409-432. Cambridge, Cambridge University Press.

Khanum A. 1982. An ecological study of freshwater algal mats. Bot. Bull. Academia Sinica. 23: 89-104.

KiRCHNER O. 1878. Kryptogamenflora von Schlesien. Jahresber. Schles. Ges. Vaterl. Cult. 2,1: 3-284.

KozŁowski W. 1895. Przyczynek do flory wodorostów okolic Warszawy. Pamiętn. Fizjogr. 13:63-73.

KuCZYŃSKA-KIPPEN N. 2009. Funkcjonowanie zbiorowisk planktonu z zróżnicowanych siedliskowo drobnych zbiornikach wodnych Wielkopolski. Ss. 504. BONAMI Wydawnictwo - Drukarnia, Poznań.

Maнато A. K. 1999. A new species of Oedogonium (Chlorophyceae, Oedogoniales) from Bihar, India. Feddes Repertorium 110 (34):173-176.

Messyasz B., Pikosz M., Schroeder G., Łęska B. \& FabROWSKA J. 2015. Identification and Ecology of Macroalgae Species Existing in Poland. Chapter 2, In: S. K. KIM \& K. ChoJnACKA (eds.). Marine Algae Extracts: Processes, Products and Applications, First Edition, pp. 17-39. Wiley - VCH.

Mirek Z., Piękoś-Mirkowa H., Zając A. \& Zając M. 2002. Flowering plants and pteridophytes of Poland. 
A checklist. In: Z. MireK (ed.). Biodiversity of Poland, 1, 442 pp. W. Szafer Institute of Botany, Polish Academy of Sciences, Kraków.

Mrozińska T. 1958. Kilka nowych dla Polski i interesujących gatunków z rodzaju Oedogonium. Fragm. Flor. Geobot. 4(1-2): 247-259.

Mrozińska T. 1981. Some species of Oedogonium New to Poland. Suplement to "Flora Polska, Oedogoniales, Chlorophyta". Fragm. Flor. Geobot. 27(4): 677-680.

Mrozińska T. 1984. Flora Polski: Zielenice (Chlorophyta) Edogoniowce (Oedogoniales), PWN, WarszawaKraków.

MroziŃSKA T. 1991. A preliminary investigation of the taxonomic classification of the genus Oedogonium Link (Oedogoniales) based on the phylogenetic relationship. Arch. Protistenk. 139: 85-101.

MrozińsKA-WeBb T. 1976. A study on epiphytic alga of the order Oedogoniales on the basis of materials from Southern Poland. Fragm. Flor. Geobot. 22 (1-2): 147-227.

Novis P. M. 2003. A taxonomic survay of Oedogonium (Oedogoniales, Chlorophyta) In the South Island and Chatham Islands, New Zeland. New Zeland Journal of Botany 41: 335-358.

Pikosz M. 2012. Oedogonium capillare (Chlorophyta, Oedogoniales) from the new site in Poland. In: M. KuCZERA (ed.). Nowe Trendy w Naukach Przyrodniczych, 3, pp. 148-156. Creative-Science-Monografia.

Pikosz M. \& Messyasz B. 2015. Composition and seasonal changes in filamentous algae in floating mats.
Oceanological and Hydrobiolocial Studies 44 (2): 273-281.

SiEminiaK D. 1979. Kilka interesujących gatunków Oedogonium (Chlorophyta) z Górnego Śląska. Fragm. Flor. Geobot. 25(3): 449-457.

Siemińska J., BĄK M., Dziedzic J., GąbKa M., Gregorowicz P., Mrozińska T., Pelechaty M., Owsianny P. M., Pliński M. \& Witkowski A. 2006. Red list the algae in Poland. In: Z. Mirek, K. Zarzycki, W. WojewodA \& Z. SzeląG (eds.). Red list of plants and fungi in Poland, pp. 35-52. W. Szafer Institute of Botany, Polish Academy of Sciences, Kraków.

SzymańsKa H., KRZYK A. \& Miętrak M. 2015. Some species of Oedogoniales (Chlorophyceae) from small astatic water bodies in the post-agricultural landscape (Masurian Landscape Park, NE Poland). Phytotaxa 192(3): 121-144. http://dx.doi.org/10.11646/phytotaxa.192.3.1.

Tiffany L. H. 1937. The filamentous algae of the west end of Lake Erie. The American Midland Naturalist 18(6): 911-951.

Venkataraman G. S. \& Natarajan K. V. 1959. Notes of some Oedogoniales from Kerala State India. Algal Laboratory, Botany Division, Indiana Agriculture Research Institute 26B(1): 7-18.

Whitton B. A., John D. M., Johnson L. R., Boulton P. N. G., Kelly M. G. \& Haworth E. Y. 1998. A coded list of freshwater algae of the British Isles. LOIS Publication 222: 1-274. Wallingford, Institute of Hydrology $\&$ NERC. 